\title{
Election Results and Opportunistic Policies: A New Test of the Rational Political Business Cycle Model*
}

\author{
Toke S. Aidt ${ }^{a \dagger} \quad$ Francisco José Veiga ${ }^{b}$ \\ Linda Gonçalves Veiga ${ }^{c}$ \\ ${ }^{a}$ University of Cambridge, Faculty of Economics, Sidgwick Avenue \\ Cambridge, CB3 9DD, United Kingdom. E-mail: Toke.Aidt@econ.cam.ac.uk \\ ${ }^{b}$ Universidade do Minho and NIPE, Escola de Economia e Gestão \\ 4710-057 Braga, Portugal. E-mail: fjveiga@eeg.uminho.pt \\ ${ }^{c}$ Universidade do Minho and NIPE, Escola de Economia e Gestão \\ 4710-057 Braga, Portugal. E-mail: linda@eeg.uminho.pt
}

September 2, 2009

\begin{abstract}
The literature on the rational political business cycle suggests that politicians systematically manipulate economic and fiscal conditions before elections to increase their chance of gaining reelection. Most tests of this theory look for evidence of preelection distortions in fiscal policy. We propose a new test that, instead, explores the implied two-way interaction between the magnitude of the opportunistic distortion and the margin of victory. The test is implemented using a panel of 278 Portuguese municipalities (from 1979 to 2005). The results show that (1) opportunism pays off, leading to a larger win-margin for the incumbent; 2 ) incumbents behave more opportunistically when their win-margin is small. These results are consistent with the theoretical model.

Keywords: Voting and popularity functions, opportunism, rational political business cycles, local government, system estimation, Portugal.

JEL codes: D72, E32, H72.
\end{abstract}

*The authors acknowledge helpful comments from Eric Dubois, Martin Gassebner, Luís AguiarConraria, David Myatt, Allan Drazen, Henry Chappell and participants in the 2007 Silvaplana Workshop on Political Economy. Francisco Veiga and Linda Veiga wish to thank the Portuguese Foundation for Science and Technology (FCT) for funding the project "Political competition and economic performance" under research grant PDTC/ECO/65711/2006 (funded by FCT and FEDER).

${ }^{\dagger}$ Corresponding author: Toke.Aidt@econ.cam.ac.uk 


\section{Introduction}

To what extent are economic policies in democratic societies distorted by the competitive struggle for votes? How strong is the impact of the economy on election results? These are important questions which have received considerable attention from researchers at least since the 1970s. ${ }^{1}$ The most recent evidence on the political business cycle suggests that the magnitude of electoral budget cycles increases with the size of the rent that politicians can earn by remaining in office and with the share of uninformed voters in the electorate (Shi and Svensson, 2006); that opportunistic fiscal manipulations are more pronounced in "new" than in "established" democracies (Brender and Drazen, 2005) but that, conditional on the degree of fiscal transparency, political business cycles are equally likely in advanced industrialized economies (Alt and Lassen, 2006) and the misallocation of public spending is likely to endure, even though countries gain experience in electoral politics (Vergne, 2009). Moreover, the evidence also supports the view that benign economic conditions, as well as pre-election fiscal manipulations, help politicians win elections (Frey and Schneider, 1978a,b; Alesina et al., 1993; Akhmedov and Zhuravskaya, 2004; Drazen and Eslava, $2005) .^{2}$

The purpose of this paper is to provide a new test of the rational political business cycle theory (RPBC) developed by Rogoff and Sibert (1988) and Rogoff (1990). For that purpose, we develop and empirically test a novel extension of the RPBC model. This theory has previously been tested by looking for distortions in fiscal outcomes before elections, but not by studying its implications for the joint determination of the winmargin of the incumbent and the fiscal distortion. The theory predicts that competent politicians manipulate budget decisions before elections to signal their competency and in that way to increase their chance of winning. In other words, not only is fiscal policy distorted in predictable ways before elections, but these distortions should increase the expected win-margin of the incumbent. The theory also implies that the incentive to

\footnotetext{
${ }^{1}$ See, e.g., Goodhart and Bhansali (1970), Mueller (1970), and Kramer (1971), Nordhaus (1975), Hibbs (1977) and Alesina (1987).

${ }^{2}$ A dissenting view is presented by Brender and Drazen (2008), who find that running deficits in an election year is not an effective tool to help reelection.
} 
distort policy depends on the expected win-margin. The nature of this feedback from prospective electoral success to pre-electoral fiscal manipulation is, however, complex. The key attribute of the theory is that the win-margin and the fiscal distortion created by opportunistic politicians are jointly determined. Empirical relations explaining these two variables should therefore be estimated together to properly test the theory.

To set the stage for our test, we first develop a version of the canonical RPBC model. We use the model to derive the two reduced-form equations to be estimated, to make precise predictions about the nature of the two-way relationship between the win-margin and the opportunistic distortion, and to motivate the exclusion restrictions needed to estimate the two-way relationship empirically. We then estimate these equations on data from 278 Portuguese municipalities from 1979 to 2005 (eight elections) using a Generalized Method of Moments (GMM) system estimator. Data from Portuguese municipalities is particularly well-suited for this purpose. First, the mayor is the principal decision-maker in the municipality and is in a position from which he can manipulate important expenditure items for election purposes. Second, all Portuguese municipalities operate under the same institutional framework and have access to the same policy instruments. This allows us to avoid many of the pitfalls associated with cross national studies. ${ }^{3}$ Finally, election dates are fixed and exogenous from the perspective of the local authorities, and all municipalities have elections on the same day.

Our estimations are consistent with the underlying theory. We find that the magnitude of the opportunistic distortion increases the win-margin and conversely, that the winmargin has a negative effect on the opportunistic distortion. We interpret this as saying that opportunism, on the one hand, pays off. On the other hand, politicians are more willing to distort policy choices when faced with a close election race and the (expected) win-margin is small.

The article is organized as follows. Section 2 describes the model and derives the two

\footnotetext{
${ }^{3}$ Blais and Nadeau (1992) and Rosenberg (1992) were the first to test political budgetary cycles using local data. For an extended revision of the empirical literature about the U.S. see Besley and Case (2003). For studies about Germany see Seitz (2000) and Galli and Rossi (2002). For Sweden see Petterson-Lidbom (2001). Finally, see Akhmedov and Zhuravskaya (2004) for Russia, Drazen and Eslava (2005) for Colombia, and Veiga and Veiga (2007) for Portugal.
} 
equations to be estimated. Section 3 discusses the data sources, institutional information about the Portuguese municipalities, and the empirical strategy adopted. Section 4 presents the empirical results. Finally, section 5 contains the conclusions.

\section{Theory}

In this section, we lay out a version of the rational political business cycle model developed by Rogoff (1990) and Rogoff and Sibert (1988). The purpose of the exercise is, firstly, to draw out implications of the theory which have not yet been subject to systematic testing and, secondly, to allow theory to guide our empirical identification strategy.

\section{$2.1 \quad$ The model}

We consider a simple two-period economy $(t=1,2)$ populated with a continuum of citizenvoters. ${ }^{4}$ Citizen-voters care about private consumption $\left(c_{t}\right)$ and two types of public goods $\left(g_{1, t}\right.$ and $\left.g_{2, t+1}\right)$. Spending on public good $1\left(g_{1}\right)$ is visible and observed immediately within the period. Spending on public good $2\left(g_{2}\right)$, on the other hand, is hard to observe and, as a consequence, citizen-voters cannot infer how much was spent on this good until later (with a one period time lag) when they observe the provision levels generated by past spending. For simplicity, we shall refer to public good 1 as an "observable" and to public good 2 as an "unobservable" public good, respectively. The life-time utility from public goods of a representative citizen-voter is

$$
u^{v}=c_{1}+\ln g_{1,1}+\theta \ln g_{2,1}+\beta\left(c_{2}+\ln g_{1,2}+\theta \ln g_{2,2}\right)
$$

where $\beta \in(0,1)$ is the discount factor and $\theta$ is the relative importance of unobservable public goods. ${ }^{5}$ Each citizen-voter is endowed with $y$ units of a non-storable good each period, pays the lump sum tax $\tau_{t}$ and consumes $c_{t}=y-\tau_{t}$. Public goods are produced from tax revenues by an elected politician using a simple linear technology:

$$
g_{1, t}+g_{2, t+1}=\tau_{t}+\varepsilon_{t}
$$

\footnotetext{
${ }^{4}$ The model is a simplified version of Rogoff (1990).

${ }^{5}$ We assume that $g_{2,1}=1$.
} 
where $\varepsilon_{t}$ is a stochastic competency term. We note that the cost of the unobservable public good provided in period $t+1$ is incurred in period $t$.

Each period a citizen-voter is elected to run the government and to produce public goods. To simplify the analysis, we assume that $\tau$ is exogenously given and that the politician, therefore, only has to decide on the allocation of resources between the two types of public goods. Citizen-voters differ with respect to their talent for being politicians and some are more competent than others. Specifically, a citizen-voter is either competent $\left(\varepsilon_{t}=\varepsilon_{H}\right)$ or incompetent $\left(\varepsilon_{t}=\varepsilon_{L}<\varepsilon_{H}\right)$ as a politician. We assume that competency is permanent, i.e., if a politician is competent in period 1 he is also competent in period 2 and vice versa. The probability that a randomly selected citizen-voter is competent is $\rho \in(0,1)$. Politicians derive utility from private and public goods, but also care about holding office per se because of the power or prestige that goes with it. To capture this, we assume that politicians receive the ego-rent $m$ per period in office.

In addition to competency and the implied provision level of public goods, citizen-voters also care about the ideology of their elected politician. This is modelled as a random shock to citizen-voters' preference for the incumbent relative to that of the challenger in each election. Specifically, we assume that the advantage (or disadvantage) of the incumbent at time $t$ is

$$
\alpha_{t}=\mu-\sigma v_{t}
$$

where $\mu$ and $\sigma$ are parameters and $\sigma>0$. The random variable $v_{t}$ captures ideological shocks. It is drawn before each election from a symmetric unimodal distribution $F\left(v_{t}\right)$ with zero mean and variance one. We assume that $F$ is differentiable and denote the density function by $f$. The ideological shock lasts for one period only and is unrelated to competency. The parameter $\mu$ captures the average incumbency advantage (or disadvantage).

The information structure of the model can best be laid out by listing the timing of events:

1. At the beginning of period 1 , the incumbent observes his competency $\varepsilon_{1}$ and decides on how to allocate resources between the two public goods $\left(g_{1,1}, g_{2,2}\right)$. 
2. Voters observe $\alpha_{1}$ and how much is provided of the observable public good $\left(g_{1,1}\right)$.

3. At the end of period 1, an election takes place where the incumbent runs against a randomly chosen challenger. The incumbent is reelected if he is supported by a majority of citizen-voters; otherwise the challenger takes office.

4. At the beginning of period 2, the incumbent, if reelected, decides how much to spend on the observable public good. ${ }^{6}$ If the challenger is elected, she observes her competency $\left(\varepsilon_{2}\right)$ and decides on how much to spend on the observable public good.

We notice that the incumbent in period 1 does not observe the ideological bias $\left(v_{t}\right)$ until after he has decided fiscal policy for the period. This, as we shall see, implies that he cannot be sure about the outcome of the election. He does, however, know the distribution and that allows him to form a judgement about how big or small his advantage is on average.

The structure described above is a sequential game of incomplete information and the natural solution concept is Perfect Bayesian Equilibrium (PBE). A PBE is a pair of firstperiod fiscal allocations $\left\{g_{1, t}^{L}, g_{1, t}^{H}\right\}$, one for each type, and a reelection rule for citizen-voters (that determines the probability of reelecting the incumbent as a function of observed fiscal policy) such that the incumbent of each type selects an optimal fiscal allocation given the reelection rule; citizen-voters' reelection rule is optimal given their beliefs about the type of the incumbent and the incumbent's strategies; and beliefs are whenever possible updated according to Bayes's rule. To narrow down the set of equilibria, we shall impose additional restrictions on out-of-equilibrium beliefs below.

\section{$2.2 \quad$ Equilibria}

We begin by noting that the optimal fiscal policy in the second period is to invest all resources in the observable public good and so $g_{1,2}=\tau+\varepsilon_{i}$ irrespective of the type of the second-period incumbent. Supposing that the first-period incumbent is reelected, we can

\footnotetext{
${ }^{6}$ In period 2, nothing is invested in the unobservable public good because it is the last period.
} 
write the second-period utility of a citizen-voter, net of the benefit of the unobservable public good, as a function of the type of the first-period incumbent as

$$
W(i)=y-\tau+\ln \left(\tau+\varepsilon_{i}\right) \text { for } i \in\{L, H\},
$$

The corresponding net second-period utility if a challenger of unknown type is elected is

$$
W(C)=y-\tau+\rho \ln \left(\tau+\varepsilon_{H}\right)+(1-\rho) \ln \left(\tau+\varepsilon_{L}\right),
$$

where $C$ represents "challenger". If citizen-voters only cared about provision of public goods, then it is clear from these expressions that they would reelect an incumbent who is known to be competent for sure and boot out an incumbent who is known to be incompetent. However, in practice citizen-voters also care about ideology and a representative citizen-voter casts a vote in favour of the incumbent if and only if

$$
\widehat{\rho}\left(g_{1,1}\right) W(H)+\left(1-\widehat{\rho}\left(g_{1,1}\right)\right) W(L)-W(C)+\alpha_{1} \geq 0
$$

where $\widehat{\rho}\left(g_{1,1}\right)$ represents the citizen-voters' updated beliefs (that the incumbent is of type $H$ ) after having observed the first-period investment in observable public goods. From the point of view of the first-period incumbent, who does not observe $v_{1}$ until after he has decided on fiscal policy, the probability of getting reelected is

$$
\pi\left(\widehat{\rho}\left(g_{1,1}\right)\right)=F\left(\frac{\mu}{\sigma}+\frac{\widehat{\rho}\left(g_{1,1}\right) W(H)+\left(1-\widehat{\rho}\left(g_{1,1}\right)\right) W(L)-W(C)}{\sigma}\right)
$$

which is increasing in the belief that the incumbent is competent.

Following Snyder (1989) and others, we say that the incumbent has an advantage in the election if, under the condition that both types of incumbents choose the same level of spending and thus $\widehat{\rho}()=.\rho$, the probability of reelection is greater than $\frac{1}{2}$. Notice that for $\widehat{\rho}()=.\rho$, we have

$$
\pi(\rho)=F\left(\frac{\mu}{\sigma}\right)
$$

Since $F$ is symmetric and unimodal with zero mean, it is clear, then, that the incumbent has an advantage if and only if $\mu>0$. Moreover, the advantage is increasing in $\mu$. On the other hand, the incumbent has a disadvantage if and only $\mu<0$. 
Faced with this reelection rule, the first-period incumbent, whether competent or not, decides how to allocate resources between the two types of public goods taking into account how this choice affects his reelection chances. Following Persson and Tabellini (1990, chapter 5), it is convenient to define the following two objects: the value of beeing reelected and the cost of signalling. The (expected) value of being reelected for a politician of type $\varepsilon_{i}$ is

$$
V\left(\varepsilon_{i}\right)=m+(W(i)-W(C))
$$

He gets the ego-rent for another period and benefits (or not) from the fact that he, in expectation, is more (or less) efficient at providing public goods than a randomly chosen challenger. We assume that $m$ is sufficiently large to make $V\left(\varepsilon_{L}\right)>0$. The cost of signalling is

$$
\begin{aligned}
C\left(g_{1,1}^{i}, \varepsilon_{i}\right)= & \ln \left(\frac{\tau+\varepsilon_{i}}{1+\beta \theta}\right)+\beta \theta \ln \left(\frac{\beta \theta\left(\tau+\varepsilon_{i}\right)}{1+\beta \theta}\right) \\
& -\ln g_{1,1}^{i}-\beta \theta \ln \left(\tau+\varepsilon_{i}-g_{1,1}^{i}\right) .
\end{aligned}
$$

Signaling entails a distortion of first-period resources (too much is spent on observable public goods and too little is spent on unobservable public goods). The cost of signalling, therefore, is the difference between the short-run optimal allocation of first-period resources between the two public goods and the actual choice of allocation $\left(g_{1,1}^{i}\right) .^{7}$

Proposition 1 (Equilibrium) The unique intuitive Perfect Bayesian Equilibrium in undominated strategies is a separating equilibrium and is characterized by the following strategies and beliefs:

1. An incumbent of type $L$ sets $g_{1,1}^{L}=\frac{\tau+\varepsilon_{L}}{1+\beta \theta}$ and $g_{2,2}^{L}=\frac{\beta \theta\left(\tau+\varepsilon_{L}\right)}{1+\beta \theta}$ in period 1 . If reelected, he sets $g_{1,2}^{L}=\tau+\varepsilon_{L}$ in period 2 .

2. An incumbent of type $H$ sets $g_{1,1}^{H}=g_{1,1}^{s}$ and $g_{2,2}^{H}=\left(\tau+\varepsilon_{H}-g_{1,1}^{s}\right)$ in period 1 where

$$
g_{1,1}^{s}=\max \left\{\frac{\tau+\varepsilon_{H}}{1+\beta \theta}, g^{s}\right\}
$$

\footnotetext{
${ }^{7}$ With the logaritmic utility functions, the short-run optimal allocation is $\widehat{g}_{1,1}^{i}=\frac{\tau+\varepsilon_{i}}{1+\beta \theta}$ and $\widehat{g}_{2,2}^{i}=$ $\frac{\beta \theta\left(\tau+\varepsilon_{i}\right)}{1+\beta \theta}$.
} 


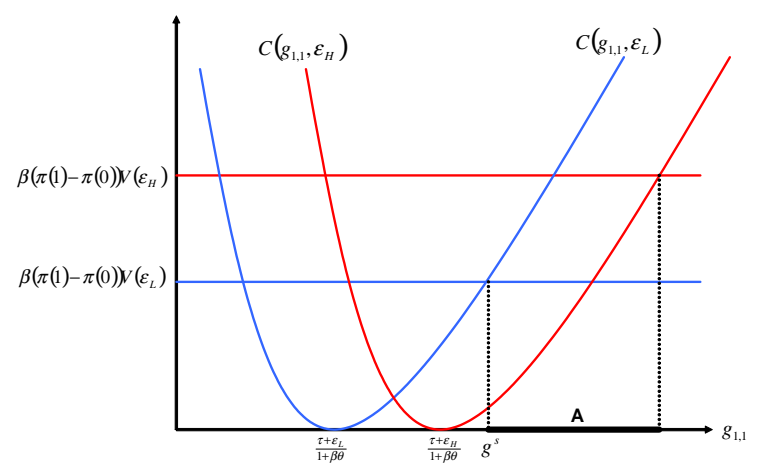

Figure 1: Separating Equilibria

with $g^{s}$ being defined as

$$
g^{s}=\max \left\{g \mid C\left(g, \varepsilon_{L}\right)=\beta\left(\pi\left(\widehat{\rho}\left(g_{1,1}^{s}\right)\right)-\pi\left(\widehat{\rho}\left(g_{1,1}^{L}\right)\right)\right) V\left(\varepsilon_{L}\right)\right\} .
$$

If reelected, he sets $g_{1,2}^{H}=\tau+\varepsilon_{H}$ in period 2

3. Citizen-voters' posterior beliefs are $\widehat{\rho}\left(g_{1,1}\right)=1$ for all $g_{1,1} \geq g_{1,1}^{s}$ and $\widehat{\rho}\left(g_{1,1}\right)=0$ for all $g_{1,1}<g_{1,1}^{s}$ and the reelection rule is given by equation (6).

\section{Proof. See Appendix}

The equilibrium is illustrated in Figure 1 where we have drawn the cost of signaling and the expected value of reelection for the two types of incumbents as a function of $g_{1,1}$.

The expected value of reelection is always larger for a competent than for an incompetent incumbent. This is because the former can provide more second-period public goods than the average politician while the latter cannot. The cost of signaling is represented by the parabolas with the competent incumbent's cost of signaling shifted to the right reflecting the fact that it is "cheaper" for the competent incumbent to increase spending on the observable public good from his short-run optimal level $\left(\frac{\tau+\varepsilon_{H}}{1+\beta \theta}\right)$ than it is for the incompetent incumbent to match it. In a separating equilibrium, an incumbent of type $L$ sets $g_{1,1}^{L}=\frac{\tau+\varepsilon_{L}}{1+\beta \theta}$ and prefers to do so rather than pretend to be competent as long as $g_{1,1}^{H}$ is no less than $g^{s}$. An incumbent of type $H$, on the other hand, is, if needed, willing to 
deviate upwards from his short-run optimal policy choice to signal to citizen-voters that he is competent as long as the cost of signaling is no greater than the expected benefit of reelection. Any $g_{1,1}^{H}$ in the interval $A$, indicated with the bold line in the Figure, constitute a separating Perfect Bayesian Equilibrium. It is clear, however, that $g_{1,1}^{H}>g^{s}$ is more costly to the competent incumbent and thus dominated by $g_{1,1}^{H}=g^{s}$. . The theory therefore predicts that observable fiscal choices are distorted before the election because competent politicians need to convince rational voters that they are indeed competent. This is the Rational Political Business Cycle (RPBC).

We can define the opportunistic distortion as

$$
\rho\left(g_{11}^{H}-\frac{\tau+\varepsilon_{H}}{1+\beta \theta}\right)
$$

which is simply a measure of the size of the average political business cycle. At equilibrium, $g_{11}^{H}$ is equal to $g^{s}$. The average reelection probability of the incumbent, which we shall call the win-margin for simplicity, can be defined as

$$
\rho \pi\left(\widehat{\rho}\left(g_{1,1}^{H}\right)\right)+(1-\rho) \pi\left(\widehat{\rho}\left(g_{1,1}^{L}\right)\right)
$$

which is the type-weighted ex ante probability that the incumbent is reelected. These two objects are jointly determined at equilibrium. On the one hand, the degree of signalling is a determinant of the win-margin because it affects the equilibrium beliefs. On the other hand, the win-margin, through its effect on the reelection differential between competent and incompetent politicians, is a determinant of the size of the opportunistic distortion.

To see how they feed on each other it is useful to entertain the following thought experiment. First, suppose that $g_{1,1}^{H}$ increases for whatever reason. When it hits $g^{s}$ there is an increase in the win-margin because type $H$ separates out. Thus, the win-margin is weakly increasing in the size of the opportunistic distortion. Second, suppose that the win-margin widens for whatever reason. The impact on the opportunistic distortion is somewhat complex. This is because what matters is not the win-margin as such but the difference between the reelection probability of a competent and an incompetent politician,

\footnotetext{
${ }^{8}$ Since reelection is random, pooling equilibria in which both types of incumbents chose $g_{1,1}=\frac{\tau+\varepsilon_{H}}{1+\beta \theta}$ in period 1 can be ruled out by the intuitive criterion.
} 


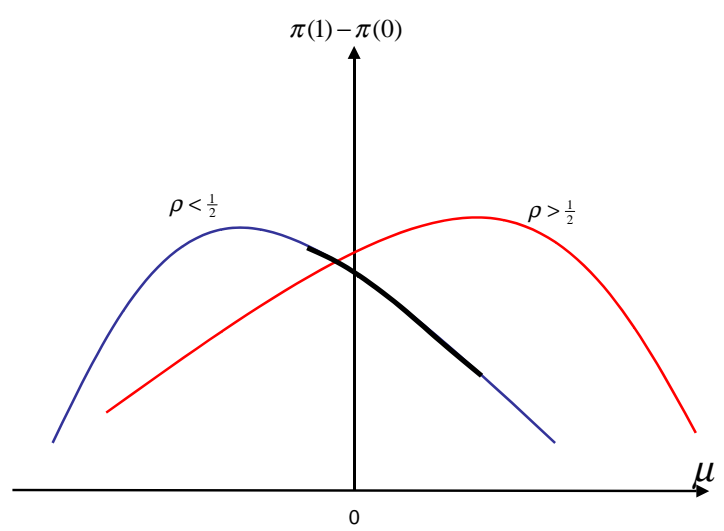

Figure 2: The relationship between incumbency advantage and the incentive to distort fiscal policy to signal competency.

$\pi\left(\widehat{\rho}\left(g_{1,1}^{H}\right)\right)-\pi\left(\widehat{\rho}\left(g_{1,1}^{L}\right)\right)$. If the reelection probability of type $H$ increases faster than that of type $L$, the opportunistic distortion becomes smaller and vice versa if it is the other way around. Thus, the impact of the win-margin on the size of the opportunistic distortion is non-monotonic depending on which of the two effects dominates.

To see this last point more clearly, we can ask what happens to the opportunistic distortion, at equilibrium, if one of the key exogenous determinants of the win-margin the advantage of the incumbent (captured by $\mu$ ) - increases. This is shown in the next proposition.

Proposition 2 (Incumbency Advantage) Assume that $g^{s}>\frac{\tau+\varepsilon_{H}}{1+\beta \theta}$. An increase (decrease) in the average advantage (disadvantage) of the incumbent ( $\mu \uparrow$ ) reduces the incentive to distort fiscal policy to signal competency if and only if

$$
\mu>\phi(\rho) \equiv W(C)-\frac{W(H)+W(L)}{2},
$$

where $\phi^{\prime}(\rho)>0$ and $\phi\left(\frac{1}{2}\right)=0$. Moreover, an increase in incumbency advantage increases the reelection chance of all types of incumbents.

Proof. See Appendix

The main implications of the proposition are illustrated in Figure 2. Recall that the incentive to distort fiscal policy to signal competency is controlled by the difference between 
the reelection probability of a competent and an incompetent politician, $\pi(1)-\pi(0) .^{9}$ This differential is a quasi-concave function of $\mu$, as illustrated in the figure for two different values of $\rho$ (the probability that a randomly selected citizen-voter is competent). The reason for this non-monotonicity is that incumbency advantage increases the election prospect of all types of incumbents. Accordingly, when an increase in $\mu$ increases the prospect of the competent type more than that of the incompetent type, the incentive to distort fiscal policy is enhanced. Conversely, the incentive is reduced if incompetent politicians benefit more from incumbency advantage than competent ones. From Figure 2 , we see that the peak of the PBC depends on $\rho$. When competency is scarce and only a small faction of the population of potential politicians is competent $\left(\rho<\frac{1}{2}\right)$, the PBC peaks when the incumbent has a disadvantage. In contrast, when there is an abundance of competent politicians in the population $\left(\rho>\frac{1}{2}\right)$, the PBC peaks when the incumbent has an advantage. Irrespective of the distribution of competency in the population, incumbency advantage eventually tempers the incentive to distort fiscal policy and $\frac{\partial(\pi(1)-\pi(0))}{\partial \mu}$ becomes negative for $\mu$ sufficiently large.

\subsection{Empirical Implications of the Theory}

We are interested in testing the relationship implied by the theory between the (average) opportunistic distortion $(O D)$ and the (average) win-margin of the incumbent $(W M)$. As discussed above, $O D$ and $W M$ are jointly determined at equilibrium. We can therefore write the structural form of the model laid out above as

$$
\begin{aligned}
W M & =h(O D, Z) \\
O D & =k(W M, X),
\end{aligned}
$$

where $h$ and $k$ are functions and $X$ and $Z$ are (possibly overlapping) vectors of other determinants of the opportunistic distortion and the win-margin.

The theory of the RPBC imposes some restrictions on $h$ and $k$. Firstly, since the posterior belief that the incumbent is competent, $\widehat{\rho}\left(g_{1,1}\right)$, is non-decreasing in $g_{1,1}$, the

\footnotetext{
${ }^{9}$ If $g^{s}<\frac{\tau+\varepsilon_{H}}{1+\beta \theta}$. the competent politician can signal his type without having to increase spending from his most-preferred choice $\left(\frac{\tau+\varepsilon_{H}}{1+\beta \theta} \cdot\right)$. In this case, the reelection differential $(\pi(1)-\pi(0))$ between competent and incompetent politicians has no effect on the size of the opportunistic distortion of fiscal policy.
} 
model predicts that opportunistic behavior pays off in the sense that the win-margin is (weakly) increasing in the size of the opportunistic distortion $\left(\frac{\partial h}{\partial O D} \geq 0\right)$. Secondly, although the theory predicts that the win-margin is a determinant of the size of the opportunistic distortion, it does not pin down the sign of the effect uniquely. An important source of variation in the win-margin is variation in incumbency advantage. Given that proposition 2 suggests that the opportunistic distortion is a quasi-concave function of the win-margin, increasing at first, then decreasing. We shall therefore in the empirical specification of $k$ allow for the possibility of such a non-monotonic relationship and let the data determine what shape it takes.

Both the win-margin and the opportunistic distortion are endogenous variables. Accordingly, to identify the links between them empirically, we need to impose restrictions on the structural form. We use the theory to motivate some of these exclusion restrictions. Firstly, we note that the parameter $\theta$, which controls the relative importance of unobservable versus observable public goods, affects the opportunistic distortion directly, while its impact on the win-margin is indirect (through its effect on the opportunistic distortion). In particular, the larger is $\theta$, the higher the cost of signaling and the lower is $g^{s}$ and, ceteris paribus, the opportunistic distortion. ${ }^{10}$ More broadly, we can interpret $\theta$ as a measure of voter awareness of the opportunity cost of spending on easily observable expenditure items. Secondly, the availability of funds $(\tau)$ also has a direct (positive) effect on $g^{s}$ because the cost of signalling falls and the value of reelection $\left(V\left(\varepsilon_{L}\right)\right)$ increases, while the effect on the win-margin is indirect. Thirdly, the ego-rent increases the benefit of reelection and directly increases the opportunistic distortion. Based on these observations, it is reasonable to exclude factors that affect voter awareness, the availability of funds and the ego-rent from the equation for the win-margin. On the other hand, the opportunistic distortion is unlikely to be directly affected by general economic conditions, while these

${ }^{10}$ Differentiating equation (10) with respect to $\theta$ gives:

$$
\frac{\partial C\left(., \varepsilon_{L}\right)}{\partial \theta}=\ln \left(\frac{\beta \theta\left(\tau+\varepsilon_{L}\right)}{1+\beta \theta}\right)-\ln \left(\tau+\varepsilon_{L}-g^{s}\right)+\frac{1}{\theta(1+\beta \theta)}>0 .
$$

This implies that $\frac{\partial g^{s}}{\partial \theta}<0$. Since $\frac{\left(\tau+\varepsilon_{H}\right)}{1+\beta \theta}$ also decreases in $\theta$, the overall effect on the opportunistic distortion is ambiguous. 
factors are likely to affect the win-margin directly. We shall build on this identification strategy in the empirical specification below and define $X$ and $Z$ accordingly.

\section{Data and Empirical Specification}

The data set consists of political, financial and economic variables for the 278 Portuguese mainland municipalities, for the period 1979-2005. Municipal election dates and results were obtained from the Technical Staff for Matters Concerning the Electoral Process (Secretariado Técnico dos Assuntos para o Processo Eleitoral - STAPE) of the Internal Affairs Ministry. Data on municipal local accounts was obtained from the local authority's (Direcção Geral das Autarquias Locais - DGAL) annual publication called Finanças Municipais (Municipal Finances). This report exists from 1979 to 1983 and from 1986 to 2006. For the two missing years data was obtained directly from the municipalities' official accounts and are incomplete: we have 182 observations for 1984 and 189 for 1985 . The consumer price index and the national unemployment rate were taken from the OECD's Main Economic Indicators. Data on the total number of employees in firms within each municipality and on their average wages, from 1985 to 2005, was obtained from the "Quadros de Pessoal" database, of the Portuguese Ministry of Labour and Social Solidarity (MTSS). ${ }^{11}$ Finally, demographic data was obtained from the National Statistics Office (INE).

The Portuguese municipalities were formally established by the Constitution of 1976, after the bloodless military coup of April 25, 1974, which put an end to 48 years of dictatorship. The first municipal election took place in December of 1976. Until 1985 elections were held every third year and after that every fourth year. Election dates are fixed nationally and therefore exogenous from the perspective of the municipalities. During our sample period (1979-2005), all elections took place in December, except for an election in October of 2005, and there were no legal restrictions on the number of times a mayor could stand for election.

\footnotetext{
${ }^{11}$ The "Quadros de Pessoal" is a yearly mandatory employment survey that covers virtually all privately owned firms employing paid labor in Portugal (public servants and own employment are not included). Unfortunately, there is no data on wages for 2001. In order to avoid missing values, for each municipality, we set the wages for 2001 equal to the simple average between those of 2000 and 2002.
} 
The municipalities are governed by the Municipal Assembly and the Town Council. ${ }^{12}$ The Municipal Assembly has deliberative power and it approves the general policy framework. The presidents of the councils of the freguesias, ${ }^{13}$ which make up each municipality, are automatically members of the Assembly, while the rest are elected directly by the voters registered in the municipality. The Town Council holds executive power and it designs and implements local policies. Its members are all elected directly by citizens who vote for party or independent lists of candidates. ${ }^{14}$ The top candidate from the list that receives the most votes becomes mayor. The mayor is the president of the Town Council and plays a leading role in the executive and has substantial power and autonomy.

Portuguese municipalities are responsible for a large variety of activities, ranging from urban planning and territory organization to the supply of local public services and regulation. The local public services controlled by the municipalities include sewage, distribution of water and energy, local transportation and communication, elementary education, patrimony, promotion of culture and science, provision of recreation and sports facilities, local health care, social housing, environmental protection and municipal policing. The municipalities operate within the same institutional framework and are all subject to the same financial regime. ${ }^{15,16}$ With this common regime, the municipalities are financially autonomous and can, without authorization from a higher-ranked authority, define their own budget, collect the revenues they are entitled to by law and allocate expenditures. ${ }^{17}$ Nonetheless, the Town Council and the mayor who heads it have relatively little discretionary power with regard to revenues, as, on average, $70 \%$ of per capita revenues are transfers from the central government and/or from the European Union. Moreover, the

\footnotetext{
${ }^{12}$ Law 169/99 establishes the competencies and the legal framework for the various branches of the municipalities.

${ }^{13}$ Freguesias are subdivisions of municipalities. They are the lowest administrative unit in Portugal.

${ }^{14}$ Votes are transformed into seats using the Hondt method. After all the votes have been tallied, the following quotient $(\mathrm{V} /(\mathrm{S}+1))$ is calculated for each party, where $\mathrm{V}$ is the total number of votes that the list received and $\mathrm{S}$ is the number of seats that the party has been allocated so far (initially 0 for all parties). The party having the highest quotient gets the first seat allocated, and its quotient is recalculated given its new seat total. The process is repeated until all seats have been allocated.

${ }^{15}$ During the period analyzed four local finance laws were introduced: Law 1/79, Decree-Law 98/84, Law $1 / 87$, and Law 42/98.

${ }^{16}$ For a detailed description of municipal finances in Portugal, see Veiga and Veiga (2007).

${ }^{17}$ They are of course subject to several control mechanisms by central government agencies, but these are merely inspective.
} 
bulk of current expenditures go to salaries, expenditures on electricity, water, etc., and are largely non-discretionary and hard to manipulate. Importantly, however, the mayors can control the level and timing of capital expenditures (of which investment expenditures are the main component), which, along with the fact that these are highly visible spending items, make them appropriate targets for mayors willing to woo voters to win elections.

As discussed above, our empirical model consists of a system of two simultaneous equations: a vote function representing the win-margin and an equation for the opportunistic distortion. We measure the win-margin of the incumbent as the difference between the vote share of the mayor's party and that of the largest opposition party. We measure the opportunistic distortion as the percentage deviation of investment expenditures $(I E)$ in an election year from the election term average. ${ }^{18}$ The later choice is motivated by the fact that opportunistic distortions are, in practice, most likely to show up in budgetary items whose timing of implementation is controlled by the mayor and which are visible to the electorate. As noted above, the municipalities do not have much freedom to set revenue instruments, as transfers from the national government represent the main source of funding, and current expenditures are strongly conditioned by salaries which are regulated by rigid labor contracts. Accordingly, investment expenditures, which are largely controlled by the mayors, are the most likely place to look for evidence of opportunistic behavior. ${ }^{19}$

Based on the discussion of exclusion restrictions above, we can expand equations (16) and (17) as follows:

$$
\begin{gathered}
W M_{i t}=\beta_{1} O D_{i t}+\beta_{2} I E_{i t}+\beta_{3} Y M_{i t}+\beta_{4} R R_{i t} \\
+\beta_{5} W M_{i, \text { prev.el. }}+\beta_{6} G P_{i t}+\beta_{7} E m p_{i t} \\
+\beta_{8} \text { Wages }_{i t}+\nu_{i}+\delta_{t}+\epsilon_{i t} \\
O D_{i t}=\phi_{0} W M_{i t}+\phi_{1}\left(W M_{i t}\right)^{2}+\phi_{2} I E_{i t}+\phi_{3} Y M_{i t}+\phi_{4} R R_{i t} \\
+\phi_{5} C_{\text {Ttm }}+\phi_{6} \Delta C T_{i t}+\phi_{7}{\text { Pop } 65_{i t}} \\
+\phi_{8} \text { PopDens }_{i t}+\phi_{9} \text { Right }_{i t}+\gamma_{i}+\varphi_{t}+\mu_{i t}
\end{gathered}
$$

\footnotetext{
${ }^{18}$ In the empirical tests, we will also use the percentage deviation of investment expenditures from their trend (obtained using the Hodrick-Prescott filter), as a robustness check.

${ }^{19}$ For results indicating that opportunism occurs in investment expenditures, see Veiga and Veiga (2007).
} 
where $i=1, \ldots ., 278$ is the index for municipalities and $t$ indicates election years. ${ }^{20}$ Both equations include municipal fixed effects $\left(\gamma_{i}\right.$ and $\left.v_{i}\right)$ and election year fixed effects $\left(\varphi_{t}\right.$ and $\left.\delta_{t}\right)$. $\beta_{1}$ to $\beta_{8}$ and $\phi_{0}$ to $\phi_{9}$ are parameters to be estimated and $\mu_{i t}$ and $\epsilon_{i t}$ are random error terms with $E\left(\mu_{i t}\right)=E\left(\epsilon_{i t}\right)=0$. Our main objective is to estimate jointly the effect of opportunism $(O D)$ on the win-margin $(W M)$ and the effect of the win-margin on the degree of opportunism. The theoretical analysis suggests that $\beta_{1}>0$ and that $\phi_{0}>0$ and $\phi_{1}<0$.

We divide the exogenous variables into three groups. The first group contains three variables that are included in both equations. They are: average investment expenditures during the election term preceding the election of year $t(I E)$; the number of years the incumbent mayor has been in office $(Y M)$; and a dummy variable equal to 1 if the incumbent mayor runs for reelection and 0 otherwise $(R R)$. We expect that low average investment expenditures ( $I E)$ make it easier to be opportunistic and to create a large percentage deviation of investment expenditures from the average at election times $\left(\phi_{2}<0\right)$. We also expect that average investment expenditures are positively related to the winmargin as voters reward mayors for keeping investments high on average throughout the term $\left(\beta_{2}>0\right)$. We expect that the number of years the incumbent mayor has served $(Y M)$ reduces the win-margin because, as documented by e.g., Mueller (1970), Frey and Schneider (1978a,b) and Veiga and Veiga (2004a), popularity tends to erode with time in office $\left(\beta_{3}<0\right)$, and that mayors with longer tenures are more experienced and so are more able to manage investment expenditures opportunistically $\left(\phi_{3}>0\right)$. Likewise, the party of the incumbent mayor is expected to do better when the mayor runs for reelection than when a new, often unknown, candidate is presented $\left(\beta_{4}>0\right)$. Finally, we expect that mayors who do not run for reelection $(R R=0)$ are unwilling to incur the cost of signalling and thus would not attempt to increase investments opportunistically $\left(\phi_{4}>0\right)$.

The second group contains variables that are excluded from the equation for the winmargin. Firstly, it includes two variables which are directly related to the availability of

\footnotetext{
${ }^{20}$ The election years are 1979, 1982, 1985, 1989, 1993, 1997, 2001 and 2005. The election of 1979 is not included in the analysis whenever lags, term averages or deviations from term averages are included. For the three municipalities created in 1997 (Odivelas, Trofa and Vizela) there is only election data for 2001 and 2005 .
} 
funds, namely the average capital transfer from the national government during the preceding election term $(C T t m)$ and the election year change in the capital transfer $(\Delta C T)$. Theory suggests that the availability of funds, here represented by transfers, increases the opportunistic distortion in election years without having a direct effect on the win-margin. We expect that $\phi_{5}$ and $\phi_{6}$ are positive. Secondly, the second group also includes two variables that are related to voter awareness which, as suggested by the theory, tends to reduce the magnitude of the political business cycle. Akhmedov and Zhuravskaya (2004), in their study of the budget cycle in Russian regions, use education and urbanization to measure voter awareness. Unfortunately, data on educational attainment at the municipality level is not available for the time period analyzed in this paper. But, in Portugal, older people have, on average, much less education than younger people. Thus, we can use the percentage of the population over 65 years of age (Pop65) to proxy for low average education levels ${ }^{21}$ and use population density (PopDens) to proxy for urbanization. We expect Pop65 to be associated with low and PopDens to be associated with high levels of voter awareness and we predict that $\phi_{7}>0$ and $\phi_{8}<0$. Finally, this group also includes a dummy variable that is equal to 1 if the mayor belongs to a right-wing party (Right). We have no prior on the sign of $\phi_{9}$.

The third group contains variables that are excluded from the equation for the opportunistic distortion. According to Carsey and Wright (1998), the electorate may wish to reward, or punish, the national government in second tier (local) elections. Since voters tend to punish the national government for bad economic outcomes, ${ }^{22}$ higher unemployment rates should lead to a lower percentage of votes for incumbent mayors who belong to the same party as the national government. We capture this with the variable $G P$ which is the interaction between a dummy variable that takes the value of 1 if the mayor belongs to the same party as the prime minister of Portugal and the national unemployment rate. ${ }^{23}$ A negative sign is expected for $\beta_{6}$. Since voters are expected to reward mayors who achieve high levels of municipal employment $(E m p)$ or high average municipal real wages (Wages)

\footnotetext{
${ }^{21}$ The same applies to the illiteracy rate, which will also be used in the empirical analysis.

${ }^{22}$ For evidence on the Portuguese case, at the national level, see Veiga and Veiga (2004a,b). For a survey of the international literature, see Paldam (2004).

${ }^{23}$ The interacted variables will also be included in the estimations of equation (19).
} 
during their tenure, we also expect $\beta_{7}$ and $\beta_{8}$ to be positive. Finally, we include the winmargin in the previous election $\left(W M_{i, \text { prev.el. }}\right)$. This variable picks up unobserved factors such as the mayor's personal characteristics and ideology and party affiliation of voters. We expect persistence in voter preferences (and thus in voting behavior) and predict that $\beta_{5}$ is positive.

Descriptive statistics are presented in Table 1. Since the win-margin measures the difference in the percentage of votes between the incumbent and his main opponent, it assumes a negative value in case of defeat. The win-margin in the previous election must be positive, since it refers to the results obtained by the incumbent mayor. The average of the percentage deviation of investment expenditures from the election term average is positive, indicating that mayors tend to behave opportunistically.

\section{[Insert Table 1 here]}

Equations (18) and (19) are estimated as a system of simultaneous equations, using Generalized Method of Moments (GMM) which is a robust estimator in that it does not require information of the exact distribution of the disturbances. ${ }^{24}$ GMM estimation is based upon the assumption that the disturbances in the equations are uncorrelated with a set of instrumental variables. In our estimations, the set of instrumental variables of each equation includes all exogenous right-hand side variables of both equations (including municipal and time dummies). The GMM estimator selects parameter estimates so that the correlations between the instruments and disturbances are as close to zero as possible, as defined by a criterion function. By choosing the weighting matrix in the criterion function appropriately, GMM can be made robust to heteroskedasticity and/or autocorrelation of unknown form. ${ }^{25}$

\footnotetext{
${ }^{24}$ This is an advantage relative to FIML, which assumes that the contemporaneous errors have a joint normal distribution

${ }^{25}$ In the presence of heteroskedasticity the GMM estimator brings efficiency gains relative to Three-Stage Least Squares (3SLS).
} 


\section{Results}

The results of the estimation of equations (18) and (19) using GMM are reported in the first four columns of Table 2. Robust t-statistics are shown in parenthesis and the levels of statistical significance of the estimated coefficients are signalled with asterisks. The number of observations and the adjusted R-squared for each equation are also reported. ${ }^{26}$

[Insert Table 2 here]

There is clear support for the main prediction of the RPBC model: opportunism pays off, as the opportunistic distortion has a statistically significant positive effect on the win-margin in all specifications of equation (18). In the equation for the opportunistic distortion, we allow, as suggested by the theory, for the possibility of a non-monotonic relationship between the win-margin and the fiscal distortion. We see that the win-margin has a highly statistically significant negative effect on the opportunistic distortion and that the the quadratic term it is never significant. ${ }^{27}$ This suggests that most of the data points in our sample fall on the downward sloping part of the relationship. In other words, the data strongly supports the prediction that incumbent politicians can increase their reelection chances by inflating spending in the year before an election and that they have most reason or incentive to do so when they expect their win-margin to be small. ${ }^{28}$ The later result is consistent with the theory of the RBPC. In fact, there are good reasons to think that the win-margin over the relevant range should have a monotonic negative impact on the fiscal distortion. Firstly, in practice, competency is likely to be scarce, i.e., that $\rho<\frac{1}{2}$. The main reason is that ability is widely believed to be drawn from

\footnotetext{
${ }^{26}$ The specifications include dummy variables for municipalities (municipal fixed effects) and election years. In order to check if results were sensitive to the geographical dummies chosen, two alternatives were also implemented. First, dummies for districts replaced the municipal fixed effects (there are 18 districts in mainland Portugal). Second, we included dummy variables for three of the four population categories that, according to the Portuguese law, are used to determine the mayors' wages. Results, available upon request, are virtually identical to those obtained when using municipal dummy variables.

${ }^{27}$ Since the variable WinMarginSquared is never statistically significant when included (see columns 1 and 2), it was excluded from the estimations of columns 3 to 6 . Wald tests allow for this exclusion. For the same reason, it was not included in the estimations of Tables 3 and 4.

${ }^{28}$ Results are very similar when the percentage deviation of investment expenditures from their trend (obtained using the Hodrick-Prescott filter) is used as the proxy for the opportunistic distrortion.
} 
a left-skewed distribution (e.g., a log-normal distribution). ${ }^{29}$ Secondly, a large empirical literature has established that incumbents have an advantage in winning elections. ${ }^{30}$ This suggests that $\mu$ is likely to be positive. Taken together the two observations suggest that over the empirically relevant range, the relationship between win-margin (as induced by variations in incumbency advantage) and the fiscal distortion is negative and monotonic (as illustrated by the bold segment in Figure 2).

Concerning the magnitude of the effects, a one-percentage point increase in the opportunistic distortion, increases the win-margin by approximately 0.06 to 0.08 percentage points, while a one-percentage point increase in the win-margin decreases the opportunistic distortion by 0.5 to 0.8 percentage points. Although the first effect may seem small, if a mayor, in the election year, doubles investment expenditures relative to their election term average, the win-margin increases by 6 to 8 percentage points, which could be the difference between winning and losing a close election. The second effect implies that a one-standard deviation increase in the win-margin decreases the opportunistic distortion by 10 to 16 percentage points.

Our estimates also give support to some of the secondary hypotheses. Firstly, from the estimates of equation (18) there is evidence that the win-margin is persistent, that time in office reduces the win-margin, and that the mayor's party does better when the incumbent runs for reelection. Contrary to our expectations, mayors belonging to the same party as the national government are not penalized in municipal elections for high national unemployment. ${ }^{31}$ But, there is evidence that they are penalized in general, irrespective of the state of the economy, as the dummy variable Government Party is always statistically significant with a negative sign. This may indicate that Portuguese voters wish to avoid the concentration of national and local powers in the same party, or that they use their vote in local elections to express their discontent with the national government. Municipal employment (Emp) and average real wages (Wages) turned out to be statisti-

\footnotetext{
${ }^{29}$ This observation is, for example, the basis for virtually all applied work on optimal taxation (see, e.g., Tuomala, 1990).

${ }^{30}$ See, e.g., Tompkins (1984), Levitt and Wolfram (1997) or Carson et al. (2007).

${ }^{31}$ This interaction is only statistically significant in the specification reported in column 1 , and with the wrong sign. Replacing the national unemployment rate by the inflation rate or GDP growth produces similar results.
} 
cally insignificant in the specification reported in column 1. Since the inclusion of these variables reduces the sample size substantially, because data on employment and wages is available only from 1985 onwards, we decided to exclude them from the specifications reported in the following columns and tables. Since the national unemployment rate and its interaction with the dummy for the government party are not statistically significant in column 3, they were excluded from the estimations of the following columns.

Secondly, from the estimation of equation (19), we note that the data supports the hypothesis that opportunism is greater when the incumbent runs for reelection, when she belongs to a left-wing party $($ Right $=0)$, and when there are increases in capital transfers from the national government in the election year. Contrary to our expectations, opportunism depends positively on average investment expenditures over the election term. Thus, mayors who spend more on average, also behave more opportunistically. Although average capital transfers over the election term are not statistically significant in the first two columns, they are, with a negative sign, in the following columns, indicating that municipalities that receive smaller average transfers tend to behave more opportunistically. Finally, the opportunistic distortion does not seem to depend on the number of years the mayor has been in office, on the percentage of the population over 65 years old, ${ }^{32}$ or on population density. Since these variables are never statistically significant when included, they were excluded from the estimation of column $4,{ }^{33}$ which became our baseline specification for the following columns and tables.

To check the robustness of these results to alternative system estimation methods, we also performed the estimations using Three-Stage Least Squares (3SLS) and Full Information Maximum Likelihood (FIML). 3SLS can be seen as the two-stage least squares version of the Seemingly Unrelated Regressions (SUR) method, which estimates the parameters of the system accounting for heteroskedasticity and contemporaneous correlation in the errors across equations. It is both consistent and asymptotically efficient. 3SLS is an appropriate technique when right-hand side variables are correlated with the error

\footnotetext{
${ }^{32}$ When the illiteracy rate is used instead, it is seldom statistically significant. Thus, there is no robust empirical evidence that the opportunistic distortion is affected by these proxies of voter awareness.

${ }^{33}$ It is worth noting that Wald tests allow for all the exclusions of variables referred to above.
} 
terms and there is both heteroskedasticity and contemporaneous correlation in the residuals. FIML is the asymptotically efficient estimator for linear and nonlinear simultaneous models, under the assumption that the disturbances are multivariate normal. When this assumption fails, FIML may still be asymptotically efficient. An advantage of 3SLS and GMM over FIML is that the model does not have to be fully specified; the estimates for the equations and parameters can be consistent even if the exact form of the rest of the model is unknown. One caveat of 3SLS and FIML is that they propagate to the system any specification error in the structure of the model. The results obtained when using these two alternative system estimation methods are reported in columns 5 (3SLS) and 6 (FIML) of Table 2. They are very similar to those of column 4 (GMM). Thus, regardless of the system estimation method chosen, there is clear empirical support for the theoretical predictions. ${ }^{34}$

The evidence presented in Table 2 reported findings of opportunistic distortions in investment expenditures. In Table 3, we report the results for other expenditure categories. Although the two main predictions of the RPBC model still receive empirical support in the specification with total expenditures (column 1), results are weaker than those obtained for investment expenditures: the opportunistic distortion is only weakly statistically significant in the estimation of equation (18) and the coefficient on the win-margin in equation (19) is much smaller (-0.217 against -0.508). While the results for total capital expenditures $^{35}$ are similar to those for investment expenditures (column 3), the results for current expenditures (column 2) do not accord with theory. However, as explained in section 2, Portuguese mayors have relatively little control over current expenditures and it is, therefore, not surprising that these are not opportunistically managed. Additionally, current expenditures are much less visible than investment expenditures, which makes them less attractive for opportunistic manipulation. Finally, in column 4, we used the subdivision of investment expenditures for which Veiga and Veiga (2007) found the most convincing evi-

\footnotetext{
${ }^{34}$ In order to save space, we will only report GMM results in the following tables (3 and 4). But, it is worth noting that those obtained when using 3SLS or FIML are very similar, and are available from the authors upon request.

${ }^{35}$ Total capital expenditures are composed of investment expenditures and capital transfers to freguesias (lower level of local government).
} 
dence of opportunism - Miscellaneous Construction (overpasses, streets, rural roads, etc.). Here results are clearly supportive of the theoretical model's predictions. Furthermore, the coefficient of -0.610 for the win-margin in the estimation of equation (19) is greater in absolute value than any of those obtained for other expenditure items, indicating that the opportunistic distortion is greatest for this expenditure item. ${ }^{36}$ Since the coefficient of 0.088 for the opportunistic distortion in the estimation of equation (18) is also the highest obtained in tables 2 and 3, Miscellaneous Construction is also the expenditure item for which opportunism pays off the most. This is in accordance with our expectations as it is the expenditure item that includes the most visible municipal investments .

\section{[Insert Table 3 here]}

In the first two columns of Table 4, we report results for an alternative specification where we use the level of investment expenditures in the election year instead of the percentage deviation of investment expenditures from their election term average as a measure of the opportunistic distortion. Since the former is highly correlated with the election term average, the later variable was excluded from equation (18). In equation (19), investment expenditures in the previous year replaces the term average of those expenditures, in order to better account for the persistence in this series.

[Insert Table 4 here]

Results are very similar to those of Table 2. Again, opportunism pays off, as higher investment expenditures in the election year lead to a larger win-margin for the incumbent party. Also as expected, investment expenditures in the election year are larger the smaller the (expected) win-margin is. Compared to the specification with deviations from the election term average (column 4 of Table 2), there is, however, less evidence that opportunism depends on the mayor's ideology. On the other hand, the election term average of capital transfers is highly statistically significant, with a positive sign, in all the specifications reported in Table 4. Results obtained for total expenditures (column 3) and

\footnotetext{
${ }^{36}$ These results are consistent with those of Drazen and Eslava (2005), who also find evidence of preelectoral manipulation of the composition of spending.
} 
capital expenditures (column 4) are similar, although total transfers seem to have smaller effects on the win-margin.

\section{Conclusion}

This paper adds to the literature on political business cycle by proposing and implementing a new test of the RPBC. The test explores the two-way relationship implied by the theory between the incumbent win-margin and the size of the opportunistic distortion. The empirical results clearly support the hypothesis that opportunism pays off, as greater expenditures in the election year (when compared to the election term average or, simply in euros per capita) lead to greater vote differences between the incumbent and her main opponent. There is also evidence of persistence in vote differences and of a negative effect of time in office. Moreover, we find that the mayor's party does better when the incumbent runs for reelection, but does worse when it also controls the national government. Over the empirically relevant range, we find that the magnitude of fiscal distortion is inversely related to the win-margin. Thus, the opportunistic distortion is biggest when the incumbency advantage is small. Opportunism will also be greater when the incumbent runs for reelection, when she belongs to a left-wing party, and when there are increases in capital transfers from the central government in the election year.

These results are consistent with the prediction of the rational political business cycle model and our analysis can be seen as a refinement on previous tests of this theory which have largely focused on finding pre-election distortions in fiscal variables. Our main innovation is to acknowledge the interaction between the incentive to generate cycles and the prospect of winning elections. Implementing this innovation on a large panel of Portuguese municipalities, we find support for the basic tenets of the RPBC model. Of particular interest is the finding that the cycle is largest when the need to signal is at its peak. This adds new insights to the recent literature on the political business cycle which show that the context (e.g., new versus established democracies) matter for how and when political cycles are generated. An important task for future research on political business cycles is to identify and catalog the contexts that are most likely to generate cycles and based on 
that, to consider institutional reform that can help eliminate unwarranted fluctuations in fiscal and other economic variables.

\section{Appendix}

Proof of Proposition 1 We start by constructing the set of separating equilibria and then impose restrictions on out-of-equilibrium beliefs to narrow down the set down to a singleton and to rule out pooling equilibria. Let $\left\{g_{1,1}^{L}, g_{1,1}^{H}\right\}$ denote candidate first-period equilibrium strategies of the two types of incumbents with $g_{1,1}^{L} \neq g_{1,1}^{H}$. Firstly, in any separating equilibrium an incumbent of type $L$ must chose the short-run optimal allocation of first-period resources, i.e., $g_{1,1}^{L}=\frac{\tau+\varepsilon_{L}}{1+\beta \theta}$. Thus, Bayes's rule implies that $\widehat{\rho}\left(\frac{\tau+\varepsilon_{L}}{1+\beta \theta}\right)=0$. Under the assumption that citizen-voters hold pessimistic out-of-equilibrium beliefs in the sense that for any $g_{1,1} \neq g_{1,1}^{H}, \widehat{\rho}\left(g_{1,1}\right)=0$, it would not be beneficial for an incumbent of type $L$ to pretend to be of type $H$ if

$$
C\left(g_{1,1}^{H}, \varepsilon_{L}\right) \geq \beta(\pi(1)-\pi(0)) V\left(\varepsilon_{L}\right)
$$

Moreover, an incumbent of type $H$ prefers to play $g_{1,1}^{H}$ rather than his short-run optimal choice $\frac{\tau+\varepsilon_{H}}{1+\beta \theta}$ if

$$
C\left(g_{1,1}^{H}, \varepsilon_{H}\right) \leq \beta(\pi(1)-\pi(0)) V\left(\varepsilon_{H}\right)
$$

Notice that these the two intervals overlap, that any $g_{1,1}^{H}$ within this intersection is a separating $\mathrm{PBE}$ and that the intersection may contain $\frac{\tau+\varepsilon_{H}}{1+\beta \theta}$. Call the intersection $A$. Since for $g_{1,1} \in A$ an incumbent of type $H$ is worse off the further away $g_{1,1}^{H}$ is from $\frac{\tau+\varepsilon_{H}}{1+\beta \theta}$, all separating equilibria within $A$ are dominated by $g_{1,1}^{H}=g^{s}$ (defined in equation (12)) and can be ruled out by assuming that citizen-voters hold the (out-of-equilibrium) belief that the incumbent is of type $H$ for all $g_{1,1} \in A$. Pooling equilibria in which both types set $g_{1,1}=\frac{\tau+\varepsilon_{H}}{1+\beta \theta}$ can be ruled out by the intuitive criterion (Cho and Kreps, 1987) as in Rogoff (1990). 
Proof of proposition 2 From equation (12), we note that the incentive to signal competency by distorting fiscal policy depends on

$$
\pi(1)-\pi(0)=F\left(\frac{\mu+W(H)-W(C)}{\sigma}\right)-F\left(\frac{\mu+W(L)-W(C)}{\sigma}\right) .
$$

Calculate

$$
\frac{\partial(\pi(1)-\pi(0))}{\partial \mu}=\frac{f\left(\frac{\mu+W(H)-W(C)}{\sigma}\right)-f\left(\frac{\mu+W(L)-W(C)}{\sigma}\right)}{\sigma} .
$$

We note that $\frac{\partial(\pi(1)-\pi(0))}{\partial \mu} \leq 0 \Rightarrow \frac{\partial g^{s}}{\partial \mu} \leq 0$. Since $F$ is unimodal and symmetric around zero, it follows that $\frac{\partial(\pi(1)-\pi(0))}{\partial \mu} \leq 0$ if and only if

$$
\frac{\mu+W(H)-W(C)}{\sigma}-0 \geq 0-\frac{\mu+W(L)-W(C)}{\sigma}
$$

or

$$
\mu \geq \phi(\rho) \equiv W(C)-\frac{W(H)+W(L)}{2} .
$$

We note that $\phi\left(\frac{1}{2}\right)=0$ and that $\phi^{\prime}(\rho)=\ln \left(\tau+\varepsilon_{H}\right)-\ln \left(\tau+\varepsilon_{L}\right)>0$. The observation that the reelection probability of all types of incumbents increases in $\mu$ follows immediately from equation (7)

\section{References}

[1] Akhmedov, Akhmed and Ekaterina Zhuravskaya (2004), "Opportunistic Political Cycles: Test in a Young Democracy Setting," Quarterly Journal of Economics 119, $1301-1338$.

[2] Alesina, Alberto (1987), "Macroeconomic Policy in a Two-Party System as a Repeated Game," Quarterly Journal of Economics 102, 651-678.

[3] Alesina, Alberto; Londregan, John and Howard Rosenthal (1993), "A Model of the Political Economy of the United States," American Political Science Review 87(1), $12-33$.

[4] Alt, James and David Lassen (2006), "Transparency, Political Polarization, and Political Budget Cycles in OECD Countries," American Journal of Political Science 50(3), $530-550$. 
[5] Besley, Timothy and Anne Case (2003), "Political institutions and policy choices: evidence from the United States." Journal of Economic Literature XLI(1), 7-73.

[6] Blais, A. and R. Nadeau (1992), "The electoral budget cycle." Public Choice 74, $389-403$.

[7] Brender, Adi and Allan Drazen (2005), "Political Budget Cycles in New Versus Established Democracies," Journal of Monetary Economics 52(7), 1271-1295.

[8] Brender, Adi and Allan Drazen (2008), "How Do Budget Deficits and Economic Growth Affect Reelection Prospects? Evidence from a Large Panel of Countries." American Economic Review 98(5), 2203-2220.

[9] Carsey, Thomas and Gerald Wright (1998), "State and National factors in Gubernatorial and Senatorial Elections," American Journal of Political Science 42(3), 994-1002.

[10] Carson, Jamie L., Erik J. Engstrom, Jason M. Roberts (2007), "Candidate Quality, the Personal Vote, and the Incumbency Advantage in Congress," American Political Science Review 101(2), 289-301.

[11] Cho, I-K, David M. Kreps (1987), "Signaling games and stable equilibria," Quarterly Journal of Economics 102, 179-221.

[12] DGAL (1979-1983 and 1986-2001), Finanças Municipais, Direcção Geral das Autarquias Locais (DGAL), Lisbon.

[13] Drazen, Allan and Marcela Eslava (2005), "Electoral Manipulation via Expenditure Composition: Theory and Evidence," NBER Working Paper W11085.

[14] Frey, Bruno and Friedrich Schneider (1978a), "An Empirical Study of PoliticoEconomic Interaction in the United States," Review of Economics and Statistics 60, $174-183$.

[15] Frey, Bruno and Friedrich Schneider (1978b), "A Politico-Economic Model of the United Kingdom," Economic Journal 88, 243-253. 
[16] Galli, E. and S. Rossi (2002), "Political budget cycles: the case of the Western German Länder." Public Choice 110, 283-303.

[17] Goodhart, C.A.E. and R.J. Bhansali (1970), "Political Economy," Political Studies $18,43-106$.

[18] Hibbs, Douglas (1977), "Political Parties and Macroeconomic Policy," The American Political Science Review, 7, 1467-1487.

[19] Kramer, G.H. (1971), "Short-term Fluctuations in US Voting Behavior, 1896-1964," American Political Science Review 65, 131-143.

[20] Levitt, Steven and Catherine Wolfram (1997), "Decomposing the Sources of Incumbency Advantage in the U.S. House," Legislative Studies Quarterly 22, 45-60.

[21] Mueller, John E. (1970), "Presidential popularity from Truman to Johnson," American Political Science Review 64, 18-23.

[22] Nordhaus, William (1975), "The Political Business Cycle," Review of Economic Studies $42,169-90$.

[23] Paldam, Martin (2004), "Are Vote and Popularity Functions Economically Correct?" In Rowley, Charles K. and Friedrich Schneider, Eds., The Encyclopedia of Public Choice, Vol. I, 49-59 (Kluwer Academic Publishers).

[24] Persson, Torsten and Guido Tabellini (1990), Political Economics: Explaining Economic Policy. MIT Press, Cambridge, MA.

[25] Pettersson-Lidbom, Per (2001), "An empirical investigation of the strategic use of debt," Journal of Political Economy 109(3), 570-583.

[26] Rogoff, Kenneth (1990), "Equilibrium Political Budget Cycles," American Economic Review 80, 21-36.

[27] Rogoff, Kenneth and Anne Sibert (1988), "Elections and Macroeconomic Policy Cycles," Review of Economics Studies 55, 1-16. 
[28] Rosenberg, J. (1992), "Rationality and the political business cycle: The Case of Local Government," Public Choice 73, 71-81.

[29] Seitz, H. (2000), "Fiscal policy, deficits and politics of subnational governments: The case of the German Laender." Public Choice 102, 183-218.

[30] Shi, Min and Jacob Svensson (2006), "Political budget cycles: Do they differ across countries and why?" Journal of Public Economics 90, 1367- 1389.

[31] Snyder, James (1989), "Election goals and the allocation of campaign resources," Econometrica 57(3), 637-660.

[32] Tompkins, Mark (1984), "The Electoral Fortunes of Gubernatorial Incumbents: 19471981," Journal of Politics 46, 520-43.

[33] Tuomala, Matti (1990), Optimal Income Tax and Redistribution. Clarendon Press, Oxford, UK.

[34] Veiga, Francisco José and Linda Gonçalves Veiga (2004a), "Popularity functions, partisan effects and support in Parliament," Economics \& Politics 16(1), 101-115.

[35] Veiga, Francisco José and Linda Gonçalves Veiga (2004b), "The Determinants of Vote Intentions in Portugal," Public Choice 118(3-4), 341-364.

[36] Veiga, Linda Gonçalves and Francisco José Veiga (2007), "Political Business Cycles at the Municipal Level," Public Choice 131(1-2), 45-64.

[37] Vergne, Clémence (2009), "Democracy, Elections and Allocation of Public Expenditures in Developing Countries," European Journal of Political Economy 25(1), 63-77. 
Table 1: Descriptive Statistics

\begin{tabular}{|c|c|c|c|c|c|c|}
\hline Variable Name & $\begin{array}{c}\text { Variable } \\
\text { Abbreviation }\end{array}$ & Obs. & Mean & $\begin{array}{l}\text { Stand. } \\
\text { Dev. }\end{array}$ & Min. & Max. \\
\hline Win-Margin (vote difference) & $W M$ & 2190 & 14.76 & 19.93 & -72.62 & 87.93 \\
\hline Win-Margin in the previous election & $W M_{\text {prev.el. }}$ & 2202 & 19.29 & 14.59 & 0.02 & 87.93 \\
\hline Investment Expenditures & $\operatorname{InvExp}$ & 2078 & 213.49 & 162.36 & 0.00 & 1627.16 \\
\hline Investment Expenditures (Term Mean) & $I E$ & 1931 & 196.81 & 131.11 & 16.00 & 1077.887 \\
\hline $\begin{array}{l}\text { Opportunistic Distortion: \% Deviation } \\
\text { of Investment Expenditures from } \\
\text { their Term Mean }\end{array}$ & $O D$ & 1805 & 10.45 & 32.07 & -88.51 & 169.52 \\
\hline Average Real Wages & Wages & 1656 & 549.04 & 141.19 & 283.32 & 1523.05 \\
\hline Capital Transfers (Term Mean) & CTtm & 1931 & 167.25 & 137.19 & 19.22 & 995.48 \\
\hline $\begin{array}{l}\% \text { Change in Capital Transfers (From } \\
\text { Previous Year) }\end{array}$ & $\triangle C T$ & 1826 & 9.33 & 39.02 & -87.38 & 288.43 \\
\hline Government's Party & GovParty & 2203 & 0.46 & 0.49 & 0.00 & 1.00 \\
\hline Municipal Employment & Emp & 2205 & 12.27 & 11.22 & 1.04 & 89.73 \\
\hline Population Density & PopDens & 2205 & 2.87 & 9.00 & 0.05 & 112.74 \\
\hline \% Population Over 65 Years Old & Pop65 & 2205 & 17.52 & 5.96 & 5.35 & 42.02 \\
\hline Right & Right & 2205 & 0.48 & 0.49 & 0.00 & 1.00 \\
\hline Run for Re-election & $R R$ & 2115 & 0.79 & 0.40 & 0.00 & 1.00 \\
\hline Unemployment Rate (National) & Unemp & 2205 & 6.60 & 1.49 & 4.07 & 9.17 \\
\hline Years Mayor & $Y M$ & 2198 & 7.39 & 4.98 & 1.00 & 29.00 \\
\hline
\end{tabular}

Sources: DGAL, INE, MTSS, OECD, STAPE. 
Table 2: Opportunism and Vote Difference

\begin{tabular}{|c|c|c|c|c|c|c|}
\hline Votes & $\begin{array}{l}\text { GMM } \\
\quad 1\end{array}$ & $\begin{array}{l}\text { GMM } \\
2\end{array}$ & $\begin{array}{c}\text { GMM } \\
3\end{array}$ & $\begin{array}{c}\text { GMM } \\
\quad 4\end{array}$ & $\begin{array}{l}\text { 3SLS } \\
5\end{array}$ & $\begin{array}{l}\text { FIML } \\
\quad 6\end{array}$ \\
\hline \multicolumn{7}{|l|}{ Equation (18): Win-margin } \\
\hline Opportunistic distortion & $\begin{array}{c}.060 \\
(2.31)^{* *}\end{array}$ & $\begin{array}{c}.075 \\
(3.10)^{* * *}\end{array}$ & $\begin{array}{c}.075 \\
(3.13)^{* * *}\end{array}$ & $\begin{array}{c}.080 \\
(3.31)^{* * *}\end{array}$ & $\begin{array}{l}.048 \\
(1.73)^{*}\end{array}$ & $\begin{array}{c}.085 \\
(3.41)^{* * *}\end{array}$ \\
\hline $\begin{array}{l}\text { Investment Expenditures } \\
\text { (Term Mean) }\end{array}$ & $\begin{array}{l}.003 \\
(1.12)\end{array}$ & $\begin{array}{c}.004 \\
(1.27)\end{array}$ & $\begin{array}{c}.006 \\
(1.98)^{* *}\end{array}$ & $\begin{array}{c}.004 \\
(1.54)\end{array}$ & $\begin{array}{l}.005 \\
(1.82)^{*}\end{array}$ & $\begin{array}{c}.004 \\
(1.28)\end{array}$ \\
\hline Years Mayor & $\begin{array}{c}-.359 \\
(-4.49)^{* * *}\end{array}$ & $\begin{array}{c}-.327 \\
(-4.06) * * *\end{array}$ & $\begin{array}{c}-.300 \\
(-3.73)^{* * * *}\end{array}$ & $\begin{array}{c}-.321 \\
(-4.12)^{* * *}\end{array}$ & $\begin{array}{c}-.329 \\
(-4.05) * * *\end{array}$ & $\begin{array}{c}-.330 \\
(-3.88) * * *\end{array}$ \\
\hline Run for Re-election & $\begin{array}{c}8.421 \\
(8.16)^{* * *}\end{array}$ & $\begin{array}{c}8.890 \\
(9.34)^{* * *}\end{array}$ & $\begin{array}{c}8.963 \\
(9.43)^{* * *}\end{array}$ & $\begin{array}{c}8.857 \\
(9.28)^{* * * *}\end{array}$ & $\begin{array}{c}8.901 \\
(8.48) * * *\end{array}$ & $\begin{array}{c}8.873 \\
(7.36)^{* * * *}\end{array}$ \\
\hline $\begin{array}{l}\text { Win-margin in previous } \\
\text { election }\end{array}$ & $\begin{array}{c}.581 \\
(16.5)^{* * *}\end{array}$ & $\begin{array}{c}.474 \\
(12.6)^{* * *}\end{array}$ & $\begin{array}{c}.451 \\
(11.9)^{* * *}\end{array}$ & $\begin{array}{c}0445 \\
(11.7)^{* * *}\end{array}$ & $\begin{array}{c}.442 \\
(15.3)^{* * *}\end{array}$ & $\begin{array}{c}.416 \\
(15.0)^{* * *}\end{array}$ \\
\hline $\begin{array}{l}\text { Government's Party * } \\
\text { Unemployment Rate }\end{array}$ & $\begin{array}{c}1.979 \\
(3.70)^{* * *}\end{array}$ & $\begin{array}{l}.756 \\
(1.43)\end{array}$ & $\begin{array}{c}.694 \\
(1.33)\end{array}$ & & & \\
\hline Government's Party & $\begin{array}{l}-13.886 \\
(-4.01)^{* * *}\end{array}$ & $\begin{array}{c}-8.921 \\
(-2.58)^{* * *}\end{array}$ & $\begin{array}{c}-8.445 \\
(-2.47)^{* *}\end{array}$ & $\begin{array}{c}-4.096 \\
(-5.40)^{* *}\end{array}$ & $\begin{array}{c}-3.748 \\
(-4.73)^{* * *}\end{array}$ & $\begin{array}{c}-3.397 \\
(-4.16)^{* * *}\end{array}$ \\
\hline $\begin{array}{l}\text { Unemployment Rate } \\
\text { (national) }\end{array}$ & $\begin{array}{l}.478 \\
(.96)\end{array}$ & $\begin{array}{c}1.372 \\
(2.78)^{* * *}\end{array}$ & $\begin{array}{l}.471 \\
(.98)\end{array}$ & & & \\
\hline Municipal Employment & $\begin{array}{l}.002 \\
(.51)\end{array}$ & & & & & \\
\hline Average Real Wages & $\begin{array}{l}.005 \\
(1.49)\end{array}$ & & & & & \\
\hline \# Observations & 1489 & 1740 & 1740 & 1740 & 1740 & 1740 \\
\hline Adjusted $\mathrm{R}^{2}$ & .22 & .18 & .18 & .17 & .18 & .17 \\
\hline \multicolumn{7}{|c|}{ Equation (19): Opportunistic distortion (\% Deviation of Investment Expenditures from their Term Mean) } \\
\hline Win-margin & $\begin{array}{c}-.674 \\
(-2.50)^{* *}\end{array}$ & $\begin{array}{c}-.808 \\
(-2.98)^{* * * *}\end{array}$ & $\begin{array}{c}-.508 \\
(-4.42)^{* * * *}\end{array}$ & $\begin{array}{c}-.532 \\
(-4.62)^{* * * *}\end{array}$ & $\begin{array}{c}-.665 \\
(-5.45)^{* * * *}\end{array}$ & $\begin{array}{c}-1.117 \\
(-7.76)^{* * * *}\end{array}$ \\
\hline Win-margin squared & $\begin{array}{c}.007 \\
(1.01)\end{array}$ & $\begin{array}{c}.009 \\
(1.48)\end{array}$ & & & & \\
\hline $\begin{array}{l}\text { Investment Expenditures } \\
\text { (term mean) }\end{array}$ & $\begin{array}{c}.003 \\
(2.24)^{* *}\end{array}$ & $\begin{array}{c}.031 \\
(2.33)^{* *}\end{array}$ & $\begin{array}{c}.041 \\
(3.11)^{* * *}\end{array}$ & $\begin{array}{c}.037 \\
(2.85)^{* * *}\end{array}$ & $\begin{array}{c}.045 \\
(3.81)^{* * *}\end{array}$ & $\begin{array}{c}.046 \\
(4.03)^{* * *}\end{array}$ \\
\hline Years Mayor & $\begin{array}{c}0.012 \\
(.07)\end{array}$ & $\begin{array}{l}-.044 \\
(-.26)\end{array}$ & $\begin{array}{l}-.242 \\
(-1.41)\end{array}$ & & & \\
\hline Run for Re-election & $\begin{array}{c}7.290 \\
(2.67)^{* * *}\end{array}$ & $\begin{array}{c}8.507 \\
(3.37)^{* * *}\end{array}$ & $\begin{array}{c}8.333 \\
(3.38)^{* * *}\end{array}$ & $\begin{array}{c}8.674 \\
(3.49)^{* * *}\end{array}$ & $\begin{array}{c}9.947 \\
(3.90) * * *\end{array}$ & $\begin{array}{c}14.909 \\
(5.21)^{* * *}\end{array}$ \\
\hline $\begin{array}{l}\text { Capital Transfers (Term } \\
\text { Mean) }\end{array}$ & $\begin{array}{l}-.007 \\
(-.47)\end{array}$ & $\begin{array}{l}-.008 \\
(-.60)\end{array}$ & $\begin{array}{c}-.051 \\
(-3.83)^{* * * *}\end{array}$ & $\begin{array}{c}-.051 \\
(-4.00) * * *\end{array}$ & $\begin{array}{c}-.047 \\
(-4.34) * * *\end{array}$ & $\begin{array}{c}-.045 \\
(-4.66) * * *\end{array}$ \\
\hline $\begin{array}{l}\text { \% Change in Capital } \\
\text { Transfers }\end{array}$ & $\begin{array}{c}.344 \\
(11.2)^{* * *}\end{array}$ & $\begin{array}{c}.330 \\
(12.0)^{* * *}\end{array}$ & $\begin{array}{c}.343 \\
(12.4)^{* * *}\end{array}$ & $\begin{array}{c}.349 \\
(12.4)^{* * * *}\end{array}$ & $\begin{array}{c}.343 \\
(15.6)^{* * *}\end{array}$ & $\begin{array}{c}.353 \\
(17.8)^{* * *}\end{array}$ \\
\hline $\begin{array}{l}\% \text { Population Over } 65 \\
\text { Years Old }\end{array}$ & $\begin{array}{l}-.089 \\
(-.43)\end{array}$ & $\begin{array}{c}.133 \\
(1.18)\end{array}$ & $\begin{array}{l}-.044 \\
(-.23)\end{array}$ & & & \\
\hline Population Density & $\begin{array}{l}.173 \\
(1.30)\end{array}$ & $\begin{array}{l}.133 \\
(1.18)\end{array}$ & $\begin{array}{l}-.022 \\
(-.19)\end{array}$ & & & \\
\hline Right & $\begin{array}{c}-6.768 \\
(-3.36)^{* * *}\end{array}$ & $\begin{array}{c}-7.434 \\
(-3.77)^{* * *}\end{array}$ & $\begin{array}{c}-7.647 \\
(-4.64)^{* * *}\end{array}$ & $\begin{array}{c}-7.426 \\
(-4.52)^{* * *}\end{array}$ & $\begin{array}{c}-6.948 \\
(-4.01)^{* * *}\end{array}$ & $\begin{array}{c}-5.268 \\
(-3.87)^{* * *}\end{array}$ \\
\hline \# Observations & 1489 & 1740 & 1740 & 1740 & 1740 & 1740 \\
\hline Adjusted $\mathrm{R}^{2}$ & .26 & .23 & .19 & .19 & .17 & .11 \\
\hline
\end{tabular}

Sources: DGAL, INE, MTSS, OECD, STAPE.

Notes: System of simultaneous equations estimated by the method indicated at the top of each column. Models estimated with a constant and with dummy variables for municipal and time specific effects. Tstatistics are in parenthesis. Significance level at which the null hypothesis is rejected: ***, $1 \%$; **, 5\%, and $*, 10 \%$. 
Table 3: Opportunism in Other Expenditure Items

\begin{tabular}{|c|c|c|c|c|}
\hline & $\begin{array}{c}\text { Total } \\
\text { Expenditures } \\
1\end{array}$ & $\begin{array}{c}\text { Current } \\
\text { Expenditures } \\
2\end{array}$ & $\begin{array}{c}\text { Capital } \\
\text { Expenditures } \\
3\end{array}$ & $\begin{array}{c}\text { Miscellaneous } \\
\text { Construction } \\
4\end{array}$ \\
\hline \multicolumn{5}{|l|}{ Equation (18): Win-margin } \\
\hline Opportunistic distortion & $\begin{array}{c}.070 \\
(1.68)^{*}\end{array}$ & $\begin{array}{l}-.077 \\
(-1.02)\end{array}$ & $\begin{array}{c}.051 \\
(2.05)^{* *}\end{array}$ & $\begin{array}{c}.088 \\
(3.24)^{* * *}\end{array}$ \\
\hline Expenditures (Term Mean) & $\begin{array}{c}-.00005 \\
(-.05)\end{array}$ & $\begin{array}{c}-.004 \\
(-1.64)^{*}\end{array}$ & $\begin{array}{c}.004 \\
(1.64)^{*}\end{array}$ & $\begin{array}{c}.004 \\
(1.03)\end{array}$ \\
\hline Years Mayor & $\begin{array}{c}-.311 \\
(-4.13)^{* * *}\end{array}$ & $\begin{array}{c}-.291 \\
(-3.67)^{* * *}\end{array}$ & $\begin{array}{c}-.315 \\
(-4.13)^{* * *}\end{array}$ & $\begin{array}{c}-.329 \\
(-4.17)^{* * *}\end{array}$ \\
\hline Run for Re-election & $\begin{array}{c}9.427 \\
(10.0)^{* * *}\end{array}$ & $\begin{array}{c}9.687 \\
(10.3)^{* * *}\end{array}$ & $\begin{array}{c}9.125 \\
(9.69)^{* * *}\end{array}$ & $\begin{array}{c}8.889 \\
(8.49)^{* * *}\end{array}$ \\
\hline $\begin{array}{l}\text { Win-margin in previous } \\
\text { election }\end{array}$ & $\begin{array}{c}.453 \\
(12.1)^{* * *}\end{array}$ & $\begin{array}{c}.459 \\
(12.0)^{* * *}\end{array}$ & $\begin{array}{c}.460 \\
(12.2)^{* * *}\end{array}$ & $\begin{array}{c}.565 \\
(15.9)^{* * *}\end{array}$ \\
\hline Government's Party & $\begin{array}{c}-3.314 \\
(-4.41)^{* * *}\end{array}$ & $\begin{array}{c}-4.181 \\
(-5.39)^{* * *}\end{array}$ & $\begin{array}{c}-3.849 \\
(-5.11)^{* * *}\end{array}$ & $\begin{array}{l}-1.363 \\
(-1.70)^{*}\end{array}$ \\
\hline $\begin{array}{l}\text { \# Observations } \\
\text { Adjusted } \mathrm{R}^{2}\end{array}$ & $\begin{array}{c}1767 \\
.19\end{array}$ & $\begin{array}{c}1767 \\
.19\end{array}$ & $\begin{array}{c}1766 \\
.20\end{array}$ & $\begin{array}{c}1489 \\
.20\end{array}$ \\
\hline \multicolumn{5}{|c|}{ Equation (19): Opportunistic distortion (\% Deviation of Expenditures from their Term Mean) } \\
\hline Win-margin & $\begin{array}{c}-.217 \\
(-5.11)^{* * *}\end{array}$ & $\begin{array}{l}-.001 \\
(-.48)\end{array}$ & $\begin{array}{c}-.295 \\
(-4.27) * * *\end{array}$ & $\begin{array}{c}-.610 \\
(-4.97) * * *\end{array}$ \\
\hline Expenditures (Term Mean) & $\begin{array}{l}-.004 \\
(-1.54)\end{array}$ & $\begin{array}{c}-.032 \\
(-7.53)^{* * *}\end{array}$ & $\begin{array}{c}-.017 \\
(-2.06)^{* *}\end{array}$ & $\begin{array}{c}.045 \\
(2.52)^{* *}\end{array}$ \\
\hline Run for Re-election & $\begin{array}{c}3.743 \\
(4.11)^{* * *}\end{array}$ & $\begin{array}{l}.425 \\
(.48)\end{array}$ & $\begin{array}{c}4.489 \\
(2.94)^{* * *}\end{array}$ & $\begin{array}{c}8.556 \\
(3.05)^{* * *}\end{array}$ \\
\hline Transfers (Term Mean) & $\begin{array}{c}.006 \\
(1.98)^{* *}\end{array}$ & $\begin{array}{c}.005 \\
(1.73)^{*}\end{array}$ & $\begin{array}{c}.020 \\
(2.27)^{* *}\end{array}$ & $\begin{array}{c}-.046 \\
(-3.57)^{* * *}\end{array}$ \\
\hline$\%$ Change in Transfers & $\begin{array}{c}.377 \\
(22.0)^{* * *}\end{array}$ & $\begin{array}{c}.106 \\
(5.56)^{* * *}\end{array}$ & $\begin{array}{c}.352 \\
(21.9)^{* * * *}\end{array}$ & $\begin{array}{c}.368 \\
(12.1)^{* * *}\end{array}$ \\
\hline Right & $\begin{array}{c}-2.028 \\
(-3.30)^{* * *}\end{array}$ & $\begin{array}{l}-1.022 \\
(-1.48)\end{array}$ & $\begin{array}{c}-3.681 \\
(-3.49)^{* * *}\end{array}$ & $\begin{array}{c}-7.328 \\
(-4.01)^{* * *}\end{array}$ \\
\hline \# Observations & 1767 & 1767 & 1766 & 1489 \\
\hline Adjusted $\mathrm{R}^{2}$ & .33 & .26 & .35 & .17 \\
\hline
\end{tabular}

Sources: DGAL, INE, MTSS, OECD, STAPE.

Notes: System of simultaneous equations estimated by GMM (with a heteroskedasticity and autocorrelation robust weighting matrix). Models estimated with a constant and with dummy variables for municipal and time specific effects. T-statistics are in parenthesis. Significance level at which the null hypothesis is rejected: $* * *, 1 \% ; * *, 5 \%$, and $*, 10 \%$. The type of municipal expenditures considered in each model is indicated at the top of the respective column. Total transfers are used in columns 1 and 2, and capital transfers in columns 3 to 6 . 
Table 4: Expenditures and Vote Difference

\begin{tabular}{|c|c|c|c|c|}
\hline & $\begin{array}{c}\text { Investment } \\
\text { Expenditures } \\
1\end{array}$ & $\begin{array}{c}\text { Investment } \\
\text { Expenditures } \\
2\end{array}$ & $\begin{array}{c}\text { Capital } \\
\text { Expenditures } \\
3\end{array}$ & $\begin{array}{c}\text { Total } \\
\text { Expenditures } \\
4\end{array}$ \\
\hline \multicolumn{5}{|l|}{ Equation (18): Win-margin } \\
\hline $\begin{array}{l}\text { Opportunistic distortion } \\
\text { (Expenditures) }\end{array}$ & $\begin{array}{c}.008 \\
(3.14)^{* * *}\end{array}$ & $\begin{array}{c}.007 \\
(2.72)^{* * *}\end{array}$ & $\begin{array}{c}.006 \\
(2.67)^{* * *}\end{array}$ & $\begin{array}{c}.002 \\
(1.70)^{*}\end{array}$ \\
\hline Years Mayor & $\begin{array}{c}-.404 \\
(-5.13) * * *\end{array}$ & $\begin{array}{c}-.355 \\
(-4.615)^{* * * *}\end{array}$ & $\begin{array}{c}-.333 \\
(-4.36) * * *\end{array}$ & $\begin{array}{c}-.341 \\
(-4.48)^{* * *}\end{array}$ \\
\hline Run for Re-election & $\begin{array}{c}8.861 \\
(8.56)^{* * *}\end{array}$ & $\begin{array}{c}9.399 \\
(10.0)^{* * *}\end{array}$ & $\begin{array}{c}9.417 \\
(10.0)^{* * *}\end{array}$ & $\begin{array}{c}9.651 \\
(10.3)^{* * *}\end{array}$ \\
\hline $\begin{array}{l}\text { Win-margin in } \\
\text { previous election }\end{array}$ & $\begin{array}{c}.580 \\
(16.9)^{* * *}\end{array}$ & $\begin{array}{c}.463 \\
(12.0)^{* * *}\end{array}$ & $\begin{array}{c}.468 \\
(12.4)^{* * *}\end{array}$ & $\begin{array}{c}.472 \\
(12.6)^{* * *}\end{array}$ \\
\hline Government's Party & $\begin{array}{l}-1.492 \\
(-1.84)^{*}\end{array}$ & $\begin{array}{c}-3.826 \\
(-4.98) * * *\end{array}$ & $\begin{array}{c}-3.928 \\
(-5.13) * * *\end{array}$ & $\begin{array}{c}-3.669 \\
(-4.80)^{* * *}\end{array}$ \\
\hline Municipal Employment & $\begin{array}{l}.055 \\
(1.14)\end{array}$ & & & \\
\hline Average Real Wages & $\begin{array}{l}.007 \\
(1.90)^{*}\end{array}$ & & & \\
\hline \# Observations & 1487 & 1738 & 1766 & 1767 \\
\hline Adjusted $\mathrm{R}^{2}$ & .22 & .19 & .19 & .19 \\
\hline \multicolumn{5}{|c|}{ Equation (19): Opportunistic distortion (Expenditures) } \\
\hline Win-margin & $\begin{array}{c}-.922 \\
(-3.26)^{* * *}\end{array}$ & $\begin{array}{c}-.987 \\
(-3.22) * * *\end{array}$ & $\begin{array}{c}-.773 \\
(-2.81)^{* * *}\end{array}$ & $\begin{array}{c}-1.092 \\
(-3.50)^{* * *}\end{array}$ \\
\hline Expenditures (-1) & $\begin{array}{c}.839 \\
(23.8)^{* * *}\end{array}$ & $\begin{array}{c}.816 \\
(22.5)^{* * *}\end{array}$ & $\begin{array}{c}.650 \\
(17.5)^{* * *}\end{array}$ & $\begin{array}{c}.835 \\
(25.6)^{* * *}\end{array}$ \\
\hline Run for Re-election & $\begin{array}{l}13.950 \\
(2.54)^{* *}\end{array}$ & $\begin{array}{l}12.542 \\
(2.17)^{* *}\end{array}$ & $\begin{array}{c}15.013 \\
(2.76)^{* * *}\end{array}$ & $\begin{array}{c}19.614 \\
(3.12)^{* * *}\end{array}$ \\
\hline Transfers (Term Mean) & $\begin{array}{c}.203 \\
(5.56)^{* * *}\end{array}$ & $\begin{array}{c}.258 \\
(5.94)^{* * *}\end{array}$ & $\begin{array}{c}.437 \\
(9.58)^{* * *}\end{array}$ & $\begin{array}{c}.275 \\
(7.88)^{* * *}\end{array}$ \\
\hline $\begin{array}{l}\% \text { Change in Transfers } \\
\text { (From Previous } \\
\text { Year) }\end{array}$ & $\begin{array}{c}1.351 \\
(16.5)^{* * *}\end{array}$ & $\begin{array}{c}1.272 \\
(16.1)^{* * *}\end{array}$ & $\begin{array}{c}1.298 \\
(17.1)^{* * *}\end{array}$ & $\begin{array}{c}2.785 \\
(18.4)^{* * *}\end{array}$ \\
\hline Right & $\begin{array}{l}-7.326 \\
(-1.79)^{*}\end{array}$ & $\begin{array}{l}-7.326 \\
(-1.71)^{*}\end{array}$ & $\begin{array}{l}-3.658 \\
(-.89)\end{array}$ & $\begin{array}{l}-12.927 \\
(-2.72)^{* * *}\end{array}$ \\
\hline \# Observations & 1487 & 1738 & 1766 & 1767 \\
\hline Adjusted $\mathrm{R}^{2}$ & .78 & .74 & .80 & .91 \\
\hline
\end{tabular}

Sources: DGAL, INE, MTSS, OECD, STAPE.

Notes: System of simultaneous equations estimated by GMM (with a heteroskedasticity and autocorrelation robust weighting matrix). Models estimated with a constant and with dummy variables for municipal and time specific effects. T-statistics are in parenthesis. Significance level at which the null hypothesis is rejected: ***, $1 \%$;**, $5 \%$, and *, $10 \%$. The type of expenditures considered in each model is indicated at the top of the respective column. Capital transfers in columns 1,2 and 4, and total transfers are used in column 3. 